\title{
"When Is A Grass Not A Grass?"
}

Arch. C. Budd, Swift Current, Saskatchewan

THE GRASS OF PARNASSUS

(Parnassia) is not, and does not even resemmble a grass. Botanists nowadays place this genus in the Saxifrage family but in earlier times this genus was placed by some in with the Sundews (Drosera) and by others with the violets. Why, I do not know. Other authorities make it a separate family, Parnassiaceae.

Grass of Parnassus is a perennial plant with all the flower stems and leaf stalks arising from the crown of the root. The leaves have long stalks and are entire margined, and either oval or cordate in shape. The flowering stems generally bear a stalkless, leaf-like bract below the middle, and at the summit bear a single creamywhite, delicately veined flower. The flower is very interesting, as besides the 5 sepals, 5 petals and 5 stamens it also bears 5 staminodia or sterile stamens. These are tiny blades bearing from 5 to 17 small gland-tipped hair-like, protuberances or filaments.

In Saskatchewan several species may perhaps be found but the common one is Northern Grass of Parnasssus (Parnassia palustris L.). It is found in moist, marshy places, and while more likely to be found in the more northerly and wooded areas, it is occasionally met with along stream banks and slough margins even in the drier south-western portions of the Province.

\section{Key to Flowers of the Prairies}

L. T. CARMICHAEL

Readers of the "Blue Jay" who are particularly interested in botany have derived great benefits and pleasures from the drawings and descriptions of prairie flowers that have been prepared for almost every recent issue of the magazine by Arch C. Budd, of Swift Current Experimental Station.

Now we have especially good news for these people. Mr. Budd's book, "Plants of the Farming and Ranching areas of the Canadian Prairies" has been printed and is ready for distribution. It is a government publication, available without charge, and may be obtained either from the Publications Branch at Ottawa, or direct from the Experimental station at Swift Current.

I cannot recommend the book too highly for those who are seriously interested in our flora. It is a large book 13" by 8", containing 339 pages, It is a complete descriptive record of practically every plant that grows in this country from Manitoba to the Rockies. It is not a complete pictoral record, but contains many plates beautifully drawn by the author, such as those which have appeared in the "Blue Jay." The drawing on the op- posite page is another example. We have never had anything like it in Western Canada before.

Previous to its publication, those of us deeply interested in this subject have had to rely on the "List of Flowering Plants of Saskatchewan," published by the University of Saskatchewan and compiled by Doctors Fraser and Russel, and on Rydberg's "Flora of the Prairies and Plains of Central North America." The latter book is illustrated and descriptive and very complete, but it was not written for the amateur. The ordinary nature enthusiasts can neither read the keys nor understand the descriptions.

Mr. Budd, however, has in some way overcome these difficulties. His descriptions are clear and concise. It was written for the prairie folk, who are keenly interested in wild flowers and who wish to extend their knowledge of that subject. It will become popular in that it meets the need for a fairly simple key.

Mr. Budd must be justly proud of this book-the result of many years of intensive study and work. His ambition in this regard has been realized. The Saskatchewan Natural History Society extend to him their sincere congratulations and thanks. 